\title{
Why Was It Europeans Who Conquered the World?
}

\author{
PHILIP T. HOFFMAN
}

By the 1700s Europeans dominated the gunpowder technology, which was surprising, because it had originated in China and been used with expertise throughout Eurasia. To account for their dominance, historians have invoked competition, but it cannot explain why they pushed this technology further than anyone else. The answer lies with a simple tournament model of military competition that allows for learning by doing. Political incentives and military conditions then explain why the rest of Eurasia fell behind Europeans in developing the gunpowder technology. The consequences were huge, from colonialism to the slave trade and even the Industrial Revolution.

I n the "great divergence" debate over when and why Europe forged ahead of the rest of Eurasia, one topic has been overlooked-namely, violence, or at least violence with gunpowder weapons. Here Europe possessed an undeniable comparative and absolute advantage, early on: European states were simply better at making and using artillery, firearms, fortifications, and armed ships than powers in other parts of the world and they had this advantage long before 1800. They used this gunpowder technology to wage war at home and to establish outposts abroad. The result was that by 1800 Europeans had conquered some 35 percent of the globe and were preying upon lucrative trade routes as far away as Asia. They took control of even more territory in the nineteenth century. ${ }^{1}$ Other forces certainly worked in their favor as well, including the diseases that they introduced into vulnerable populations, and there were limits to what firearms could do. ${ }^{2}$ Nonetheless, the gunpowder technology clearly played a large role in European conquest.

The Journal of Economic History, Vol. 72, No. 3 (September 2012). (C) The Economic History Association. All rights reserved. doi: 10.1017/S0022050712000319.

Philip T. Hoffman is Rea A. and Lela G. Axline Professor of Business Economics and Professor of History, Division of the Humanities and Social Sciences, California Institute of Technology, Pasadena, CA 91125. E-mail: pth@hss.caltech.edu.

Research for this article was supported by NSF Grants 0433358 and SES-0649062 as part of the Global Prices and Incomes Project. Numerous people have helped me by generously offering advice, criticisms, and expertise: Mary Elizabeth Berry, Dan Bogart, Philip C. Brown, John C. Brown, Warren Brown, Margaret Chen, Greg Clark, Stan Engerman, Claudia Goldin, Dave Grether, Dan Klerman, James Kung, Peter Lindert, Bozhong Li, Naomi Lamoreaux, James Lee, Guanglin Liu, Debin Ma, R. Preston McAfee, Kate Norberg, Patrick O'Brien, Sevket Pamuk, Peter Perdue, Gilles Postel-Vinay, Gary Richardson, Jean-Laurent Rosenthal, Stergios Skaperdas, Peter Temin, Harriet Zurndorfer, the late Ken Sokoloff, three anonymous referees for this JoURNAL, and its editor, Price Fishback.

${ }^{1}$ Headrick, Tools and Power; and Parker, Military Revolution, p. 5.

${ }^{2}$ Black, War. 
Why then was it the Europeans who came to dominate the technology, and not the Japanese, the Ottomans, or the Indians, who all used it with expertise? Or why wasn't it the Chinese, who had invented it?

This question has attracted a number of gifted military historians, but the closest they come to a deeper explanation is the claim that military competition in Europe gave the Europeans an edge. The argument has been formulated most cogently by Paul Kennedy, who points to Europe's competitive markets and persistent military rivalries. In his view, while military rivalry created an arms race, competitive markets fostered military innovation and kept one country from establishing an empire. ${ }^{3}$

But Kennedy's story of competition is not the final answer, for it leaves far too much unexplained. To begin, competitive markets do not always stimulate innovation. The clearest example comes from agriculture in early modern Europe, which had highly competitive markets but witnessed virtually no productivity growth. ${ }^{4}$

Nor do ongoing military rivalries always promote innovation. They failed to do so in eighteenth-century India and Southeast Asia. The case of India, as we shall see, is particularly illuminating. Like Europe, it had markets and incessant warfare, and the combatants were quick to adopt the latest weapons and tactics. The innovations, however, by and large originated in the West.

The answer lies with the peculiar form of competition in which European rulers were engaged. It was a winner-take-all tournament that spurred rulers to spend enormous sums on using the gunpowder technology in the continent's incessant wars. In the process, the technology was advanced via learning by doing. Elsewhere, however, political and military conditions were not conducive to improving the gunpowder technology. That is why the Europeans pushed the technology further than anyone else and why the rest of the world had trouble catching up.

Understanding why requires a look at the political, military, and fiscal incentives rulers faced, both in Europe and in other parts of Eurasia. We will start with Europe before 1800 and use it to motivate a simple tournament model, which will then be applied to the rest of the world. The model's predictions are borne out by quantitative and qualitative evidence; other explanations-including the argument about competition - fail such a test. The model thus gives us a deeper understanding of why Europeans came to dominate a technology that made world conquest possible.

\footnotetext{
${ }^{3}$ Kennedy, Rise, pp. 16-24.

${ }^{4}$ Hoffman, Growth.
} 
TABLE 1

FREQUENCY OF WAR IN EUROPE

\begin{tabular}{lc}
\hline \hline Period & $\begin{array}{c}\text { Average Percentage of Time Principal } \\
\text { European Powers Were at War }\end{array}$ \\
\hline $1550-1600$ & 71 \\
$1600-1650$ & 66 \\
$1650-1700$ & 54 \\
$1700-1750$ & 43 \\
$1750-1800$ & 29 \\
$1800-1850$ & 36 \\
\hline & 23
\end{tabular}

Note: The principal European powers are defined as France, Austria, Great Britain, Russia, Prussia, Spain, Netherlands, Sweden, Denmark, Turkey, and Poland.

Source: Wright, Study, p. 1, tables 29, 45, 46; Levy, War, leads to similar results.

\section{RULERS AND THEIR INCENTIVES IN EUROPE BEFORE 1800}

The states that coalesced in Europe in the waning days of the Middle Ages by and large had a single purpose, at least if we judge by the reasons why they levied taxes and borrowed money. That purpose was clearly warfare. In the major powers, some 40 to 80 percent of the budget went directly to the military, to defray the costs of armies and navies that fought almost without interruption (Table 1). The fraction of the budget devoted to war climbed even higher - to 95 percent in France during the Thirty Years War-if we add sums spent subsidizing allies or paying of the debts of past wars. ${ }^{5}$

In early modern Europe, decisions about war typically lay in the hands of a ruler such as a king or a prince. He would of course be advised by councilors and influenced by elites, and an influential minister might sometimes be dictating most of the decisions. But the assumption that a king or prince made the decisions about war is not far from historical reality. Even in eighteenth-century Britain, where Parliament and the cabinet decided whether to commence hostilities, the choices about the conduct of the war once it had begun were ultimately up to the king. ${ }^{6}$

What then made European kings take up arms? That question has to be answered if we are to understand what the tournament was. In Europe's major powers, the rulers often won control of warfare in the process of assembling their states in the late Middle Ages or the sixteenth century. In modern terms, they provided the public good of defense in return for taxes. That public good was precious, as anyone

\footnotetext{
${ }^{5}$ Hoffman and Rosenthal, "Political Economy"; and Tilly, Coercion.

${ }^{6}$ Harding, Amphibious, pp. 28-30; Lynn, "International"; Rodger, Command, p. 242; Mallett Mercenaries, p. 88; and Pettegree, "Elizabethan."
} 
who suffered through the horrors of the One Hundred Years War in France or the Thirty Years War in central Europe could testify. But the rulers of early modern Europe likely provided far more defense than their average subject would have wanted. They went on the offensive too, and not just to protect their kingdoms.

The reasons were not hard to understand. The kings and princes had been raised to fight one another, with toy soldiers, pikes, and firearms as children and actual training in their youth. Advisers like Machiavelli might tell them that princes "ought to have no object, thought, or profession but war." Their own fathers would teach them that war was a path to glory, a means to "distinguish [kings] . . . and to fulfill the great expectations ... inspired in the public," in the words of Louis XIV's instructions for his son. For them, fighting had gone beyond the needs of defense and become, in the words of Galileo, a "royal sport.",

Glory did recede as a motive for war in the eighteenth century, when the major powers might fight simply to preserve their reputation, to gain commercial advantage, or to snatch territory from weaker neighbors. But war was still "what . . rulers did." It continued to appeal to them, just as it long had attracted much of the European aristocracy.

For the major monarchs of early modern Europe, victory was thus a source of glory or a way to enhance their reputation. Grabbing territory from small neighbors did augment their resources and help strategically, but the thirst for glory and the drive to bolster their standing could push them to spend large sums even on small bits of terrain. Their goals may seem bizarre, but there are certainly modern analogues - the race to get a man on the moon, or, to take a nongovernmental example, college athletics. And although the kings might lose small amounts territory themselves, they faced no major downside risk to their thrones, at least in the larger states, for loss in battle in anything but a civil war never toppled a major monarch from his throne, at least in the years $1500-1790 .^{9}$

It now becomes clearer why the early modern rulers fought so much. What impels states to engage in hostilities is something of a mystery, at least to many economists and political scientists, who rightly ask why leaders do not simply agree to give the likely victor what he would win in a war and then spare themselves the lives and resources wasted in battle. The literature offers several reasons why such agreements prove unattainable, and why leaders go to war instead, despite all the

\footnotetext{
${ }^{7}$ Sonnino, Louis XIV , p. 124; Machiavelli, Prince, p. 247; Hale, War and Society, pp. 29-32.

${ }^{8}$ Lynn, "International"; and Bell, Total War, pp. 29-35.

${ }^{9}$ Hoffman, "Politics and Economics," Table 2. Losses in war did cost ministers their position.
} 
devastation it causes. ${ }^{10}$ Although all of these reasons apply to early modern Europe, two of them seem to fit the continent's history like a glove.

The first was that the leaders making decisions about war-early modern Europe's kings and princes - stood to win a disproportionate share of the spoils from victory but avoided a full share of the costs. They - not their subjects - were the ones who basked in glory or who burnished their military reputations when their armies were victorious. But they bore few of the costs, which fell disproportionately on their subjects. When the leaders' incentives are that biased, it can be impossible to reach any sort of bargain to avoid war, even if the leaders trade resources to compensate one another. ${ }^{11}$

There was a second obstacle to peaceful agreement as well-the difficulty of dividing the spoils of war that the early modern princes and kings were fighting over. Glory could not be divvied up. In fact, it simply vanished if there was no fighting, making the peaceful exchange of resources potentially more expensive than fighting. The same held for reputation; it too could only be earned on the battlefield. Commercial advantage would not be easy to share either, if, as was often the case, it involved a trade monopoly. And territory posed similar problems, when it offered a strategic advantage or if sovereignty or religious differences were at stake. Then even trading other resources might not work. In negotiations to end the Great Northern War between Russia and Sweden, for example, the Tsar Peter the Great told his envoy in 1715 that he would not consider giving back Riga and Swedish Livonia because that would threaten nearby Petersburg and all his other conquests in the war and thus potentially cost him more than the Swedes could ever conceivably given him in return. ${ }^{12}$ Religious strife could make negotiation itself impossible if it meant dealing with enemies of the faith. ${ }^{13}$

These obstacles to peace were not unique to early modern Europe, so they cannot be the reason why Europe came to dominate the gunpowder technology. They were at work elsewhere too, because foreign policy in other parts of Eurasia was often in the hands of kings, emperors, or warlords who could be as obsessed with glory as their European counterparts. ${ }^{14}$ But the biased incentives facing the

\footnotetext{
${ }^{10}$ Brito and Intriligator, "Conflict"; Powell, "Guns"; Fearon, "Rationalist"; and Jackson and Morelli, "Reasons."

${ }^{11}$ Jackson and Morelli, "Political Bias."

${ }^{12}$ Anisimov, Reforms, pp. 244-45.

${ }^{13}$ Mattingly, "International Diplomacy," p. 156. For the impact of past religious strife, see Fletcher and Iyigun, "Clash."

${ }^{14}$ See, for example, Berry, Hideyoshi, pp. 215-16.
} 
European princes and the indivisible spoils in their wars do at least explain why early modern Europe was wracked by virtually constant hostilities. Not that all rulers would have taken up arms. Some countries were too small, and, others like the Netherlands in the eighteenth century, were big enough to fight but tended to bow out, or at least not enter a particular conflict.

\section{A SIMPLE TOURNAMENT MODEL}

A model inspired by the conflicts in early modern Europe can help explain why Europe's kings and princes advanced the gunpowder technology and why rulers elsewhere in Eurasia lagged behind. We will sketch the model first, and then show that it fits the evidence both in early modern Europe and in other parts of Eurasia.

The requisite model has to explain decisions about going to war and military spending. Otherwise it cannot make sense of all the fighting in Europe and all the resources that went into it. It also has to account for improvements in military technology, so that we can isolate differences between Europe and Asia.

A simple model drawn from the economic literature on conflict and tournaments provides a tractable starting point. ${ }^{15}$ Although more complex models do a better job of accounting for the patterns of war and peace and of military spending that we see in the modern world, they have less to say about military technology, or about the virtually constant war that ravaged early modern Europe and parts of Asia as well. $^{16}$

Consider two risk-neutral early modern rulers who are considering whether or not to go to war. Winning the war earns the victor a prize $P$, which might be glory or territory or a commercial advantage. For the sake of simplicity, we assume the loser gets nothing, but the model will remain essentially the same if the ruler pays a penalty for losing or for failing to defend his kingdom against attack. ${ }^{17}$

\footnotetext{
${ }^{15}$ The model below is adapted from Fullerton and McAfee, "Auctioning," and Garfinkel and Skaperdas, "Economics."

${ }^{16}$ For a review of the conflict literature, see Garfinkel and Skaperdas, "Economics." The insightful model of Jackson and Morelli, "Strategic Militarization," can explain complex patterns of war and military spending. But it says relatively little about the effect of changes in the cost of war, which will be important in what follows.

${ }^{17}$ If losers pay a penalty $d$ that they can avoid by sitting out the war, then the model is identical, but with the prize raised to $P+d$ and the fixed cost $b$ described below increased to $b+d$. If the penalty only applies when the ruler sits out the war and fails to defend his realm against attack, then the only difference is that the fixed cost decreases to $b-d$.
} 
To have a chance of getting the prize, the rulers have to take the steps that many early modern rulers did if they wanted to win wars. First, they have to establish an army or a navy and set up a fiscal system to pay the military's bills. We can interpret that as paying a fixed cost $b$, which is assumed the same for both rulers. They also have to devote resources $\left(z_{i} \geq 0\right.$ for ruler $\left.i\right)$ to winning, which we can think of as the taxes raised to pay for supplies, weapons, ships, fortifications, and military personnel. Revenues from the rulers' personal possessions, though usually less significant, would count too, and so would conscription and commandeered resources, although they too were typically less important, at least in early modern Europe. We will adopt a common functional form from the conflict literature and assume that the probability of ruler $i$ winning the war if both decide to fight is $z_{i} /\left(z_{1}+z_{2}\right)$. The odds of winning are then proportional to the ratio of the resources they each mobilize.

Resources carry an average variable $\operatorname{cost} c_{i}$, which may be different for the two rulers; therefore, assume that $c_{1} \leq c_{2}$. For simplicity, assume the average variable cost $c_{i}$ is constant for all levels of resources $z_{i}{ }^{19}$ These costs are political: they include opposition to conscription and higher taxes, and resistance by elites when tax revenues they control are shifted to the central government. If these costs are too high or the expected gains from victory too low, a ruler may simply decide that it is not worth fighting. He can then sit on the sideline, as the Netherlands did in the eighteenth century. A ruler who opts out in this way expends no resources $z_{i}$ and avoids paying the fixed cost $b$ as well, but he has no chance of winning the prize. Making him pay a penalty for not defending himself against attack will only lower the fixed $\operatorname{cost} b$ and leave the model unchanged.

We assume that the rulers first decide, simultaneously, whether or not to go to war. They then choose the resources to expend, $z_{i}$. If only one ruler is willing to go to war, he has to pay the fixed cost $b$ involved in setting up an army, navy, and fiscal system, but he is certain to win the prize because he faces no opposition. He therefore devotes no resources $z_{i}$ to the military and wins $P-b$. If both go to war, then ruler $i$ can expect to earn

\footnotetext{
${ }^{18}$ Garfinkel and Skaperdas, "Economics."

${ }^{19}$ Adding constraint on the amount of resources a ruler could mobilize would not change things greatly, but it would allow the ruler of a large country to offset his opponent's lower average variable cost.
} 


$$
\frac{P z_{i}}{\sum_{1}^{2} z_{j}}-c_{i} z_{i}-b
$$

The first term in the expression is simply the probability that ruler $i$ wins times the value of the prize $P$, and the next two terms are just the cost of resources $z_{i}$ that he mobilizes and the fixed cost $b$.

The resulting game has a subgame perfect equilibrium. Only the ruler with the lower political costs (ruler 1) goes to war if $P>b$ and $P<b\left(1+c_{2} / c_{1}\right){ }^{2}$ Ruler 2 sits on the sidelines, because with his higher political costs, his expected winnings would not be enough to defray the fixed cost. Ruler 1 and obviously ruler 2 as well spend nothing on the military, and so there is no actual fighting. We will consider that outcome to be peace, even though ruler 1 has set up a military and a fiscal system to fund it.

Both rulers go to war if

$$
P \geq b\left(1+c_{2} / c_{1}\right)^{2}
$$

Inequality 2 is necessary and sufficient for there to be war in equibrium; it will hold when the prize is valuable, the fixed cost is low, and the ratio of average variable costs $c_{2} / c_{1}$ is near 1 . The ratio is always greater than or equal to 1 since $c_{2} \geq c_{1}$ and it will be near 1 when both rulers face similar political costs for mobilizing resources.

Inequality 2 ensures that military spending will be positive, but it does not guarantee that it will be large, which will be essential for learning by doing. To see when military spending will be big, consider the comparative statics of the equilibrium with war. In that equilibrium, ruler $i$ will spend

$$
z_{i}=\frac{P}{C}\left[1-\frac{c_{i}}{C}\right]
$$

on the military, where $C=c_{1}+c_{2}$, while total military spending by both rulers will be

$$
Z=z_{1}+z_{2}=P / C
$$

So total military spending $Z$ will only be large if, in addition to inequality $2, P / C$ is big, or, in other words, if the prize is valuable and 
the rulers' political costs for mobilizing resources are low. Finally, the probability that ruler $i$ wins the war will be

$$
\left(1-c_{i} / C\right)
$$

which will be higher for a ruler with a low average variable cost $c_{i}$.

We will also suppose that the two rulers do not repeat this game. They play it once, at the outset of their reigns, and we interpret the decision to go to war as a choice not about a single conflict, but rather about being bellicose or not for their entire time on the throne. If they are bellicose (if inequality 2 holds), they will fight one another repeatedly throughout their time on the throne; if not, their reigns will be peaceful. Other rulers may play the game too, including their successors, and one might therefore worry that concern for their heirs would create a repeated game. Foreign policy, however, was dictated by short-term interests and changed enough from ruler to ruler to make this a reasonable assumption. ${ }^{20}$ Furthermore, although other equilibria would in theory exist if the game were repeated, they could vanish if the prize were glory or victory over an enemy of the faith. By contrast, playing the strategy described above at each stage would always be equilibrium in the repeated game; with it there would be nothing to be gained by making the game repeated.

We thus have a model with war, military spending, and peace as well-namely, when one ruler wins the prize without any opposition and no resources are actually spent on fighting. How do improvements to military technology fit in? The technology used will be determined by a ruler's opponents. In Western Europe that was the gunpowder technology, but as we shall see, it was not the only military technology, and it was not effective against some enemies.

Whatever the military technology is, we will suppose that it progressed via learning by doing. Rulers fought wars and then used what worked against the enemy. That was typically how military technology advanced in the early modern world, whether it was weapons, organization, or tactics. The learning could take place during a war, or afterwards, when losers could copy winners and revise what they did. Conflicts in the late fifteenth century, for example, gave rise to lighter and more mobile artillery that could be mounted in and fired from gun carriages.

The learning extended to organization as well. French and English commanders who battled against Spain in the sixteenth century, for

\footnotetext{
${ }^{20}$ Mattingly, "International Diplomacy”; and Lynn, “International,” pp. 185-86.
} 
example, learned to appreciate the Spanish infantry's training, discipline, and small group cohesion. They urged their own countries to adopt the same organization. ${ }^{21}$

It is true that there were also conscious attempts to improve early modern military technology. King Philip II of Spain, for example, rewarded military inventors. ${ }^{22}$ But such efforts themselves were often triggered by successes and failures on the battlefield, such as when the French sought to make lighter and more mobile field artillery after a defeat in the Seven Years War. ${ }^{23}$ Learning by doing dominated, until at least the eighteenth century, and while advances through research became easier after 1800 , that possibility can readily be incorporated into an extended version of the model which would shed light on the nineteenth century. ${ }^{24}$

One reasonable way to conceive of the learning is to assume that it depends on the resources spent on war. Greater military spending gives a ruler more of a chance to learn, and rulers anywhere can do it - it is not peculiar to one corner of the world. We can model the relationship by assuming that each unit of resources $z$ spent gives a ruler an independent chance at a random military innovation $x$, where $x$ has an absolutely continuous cumulative distribution function $F(x)$ with support $[0, a]$. If we ignore the fact that $z$ is not an integer, then spending $z$ is like taking $z$ draws from the distribution, and the ruler who spends $z$ will obtain an innovation with a probability based on the distribution $F^{z}(x)$. If both rulers draw from the same distribution, as would be reasonable to suppose if they are fighting one another and using the same military technology, then the highest realized value of innovation in their war will come from the distribution $F^{Z}(x)$, where $Z=z_{1}+z_{2}=P / C$ is total military spending. We will interpret this best innovation as an advance in military technology. As $Z$ increases, the expected value of this best innovation will therefore rise, and $x$ will converge in probability to $a$, which can be interpreted as the limit of available knowledge. Greater knowledge will therefore make for more innovation, like more military spending. Finally, if there is no war, there is no spending or learning, so in that case we can assume that $x=0$.

Innovation is then an inadvertent byproduct of fighting wars, but what if the rulers intentionally seek to improve the military technology? If the

\footnotetext{
${ }^{21}$ La Noue, Discours, pp. 320-22, 352-57; Bonaparte and Favé, Etudes, vol. 1, pp. 65, 72; Williams, Works, c-civ; Hall, Weapons, pp. 121-22; and Parrot, Richelieu's Army, pp. 42-43.

${ }^{22}$ Goodman, Power, pp. 123-41.

${ }^{23}$ Alder, Engineering.

${ }^{24}$ For the extended model, see Hoffman, "Why Was It Europeans," which also explains the armed peace achieved by diplomacy after 1815 .
} 
innovation proceeds via learning by doing through the process of spending on war, then the probability of having the best innovation will be exactly the same as the probability of winning the war, given by the first term in expression 1 above. ${ }^{25}$ Winning the tournament for the best innovation will be the same as winning the war, with identical incentives, so there will be no difference, provided innovation comes from learning by doing.

So far this tournament is not repeated, but what happens if successive pairs of different rulers from the same two countries play the game over time, say once per reign? Let us assume that each pair of rulers can copy the best innovation from the previous round, which seems reasonable if they learn from experience. It also fits what happened in early modern Europe, where military innovations spread through espionage, efforts to copy what was successful, and Europe's longstanding market for weapons and military skills. Professional soldiers had every incentive to adopt the most effective tactics, hardware and organization. In such a situation, no ruler will have any technological lead over his rival at the start of a new round of the tournament. If the limits of available knowledge do not change and if the successive pairs of rulers continue to draw from the same distribution and fight each round, then after $n$ rounds the military technology will have a distribution $F^{Z}(x)$, where $Z$ is now the total amount expended over the $n$ rounds of the tournament. If the technology is ancient, then $x$ will be so close to $a$ that innovation will slow to a halt, as typically happens with learning by doing. ${ }^{26}$ It will also stop if wars are not fought. But if the technology is relatively new, then there will still be room for continued innovation, and the tournament will work like an idealized prize system that puts winning ideas into the public domain.

In that case, military innovation will be sustained and will not slow until the limits to knowledge begin to bind. But that will not happen if these limits change, either through the learning by doing or through advances in engineering and science. Suppose, for instance, that learning in each round of the tournament shifts the support of the distribution $F$ for the rulers in the next round to $[w, w+a]$, where $w$ is the value of the best innovation in the round that has just been played. Suppose too that the successive pairs of rulers confront the same costs and prize. They will continue fighting, and if $x$ has expected value $E(x)$ after one round, then after $k$ rounds of fighting, its expected value will be $k E(x)$. The rate of technical change in the military sector

\footnotetext{
${ }^{25}$ Fullerton and McAfee, "Auctioning."

${ }^{26}$ Lucas, "Miracle."
} 
( $E(x)$ per round, or ruler's reign) will not slow, nor will there be any limit to improvements. On the other hand, if the fighting stops - say because the fixed costs $b$ increase - then even under these favorable assumptions technical change will screech to a halt.

Fixed frontiers to knowledge are more realistic for the early modern world, at least up until the eighteenth century. ${ }^{27}$ If we assume fixed limits as a reasonable approximation throughout early modern Eurasia, then what matters for sustained improvements to military technology are continued war with large military expenditures, and a new military technology, such as the gunpowder technology, which was ripe for improvement via learning by doing.

One additional assumption here is that the winning technology spreads after every round of the tournament. If it does not and if some rulers therefore lack the latest military advances, then they will fall behind and stand a greater chance of losing against rulers who possess the cutting edge technology. Having the winning technology, though, does not make the playing field perfectly even. Even with it, a ruler with high costs $c_{i}$ will stand less of chance of winning against a low cost opponent, and if the difference in costs is big enough, he will simply avoid conflict.

Suppose now there are two technologies that are effective against different enemies. Gunpowder weapons, for example, worked well in early modern European warfare, whether on land or at sea. But until at least the seventeenth century, they were relatively ineffective against the nomads who threatened China, portions of south Asia and the Middle East, and even parts of Eastern Europe that bordered the Eurasian steppe. The mounted nomads had no cities to besiege, and they were too mobile to be targets for artillery, except when it was fired from behind the walls of fortifications. Sending the infantry chasing after them would demand too many provisions, since they could simply ride off into the steppe and live off the land. Muskets gave no advantage, because they could not easily be fired from horseback, and while pistols could, their range was limited. When fighting the nomads, the best option, at least for a long time, was simply to dispatch cavalry of mounted archers - essentially the same weapons the nomads themselves utilized. That was an ancient technology, which dated back to roughly $800 \mathrm{BC}$. In the early modern world, with fixed limits to knowledge, it could no longer be improved, although it would still be useful in war. $^{28}$

\footnotetext{
${ }^{27}$ Mokyr, Gifts.

${ }^{28}$ McNeill, Steppe; Esper, "Military"; Hellie, Enserfment; Barfield, Fronier; Rossabi, "Inner Asia"; Chase, Firearms; Gommans, Mughal; Agoston, Guns, pp. 58-59, 191; Lorge, War; and
} 
Suppose then that a ruler fights only nomads. He will use primarily mounted archers, and only a little of the gunpowder technology, and because he spends practically nothing on it, he will not advance it. If one of his successors finds himself confronting an enemy against whom gunpowder weapons are useful, then he will try to acquire the latest gunpowder weapons from abroad because his realm will lag behind. The story will be similar for a ruler who fights on two fronts, spending a fraction $g$ of his resources on the gunpowder technology and $1-g$ on mounted archers. He will improve the gunpowder technology, but at a lower rate because he spends only $g z_{i}$ on it, not $z_{i}$, and his successors too may want to import the latest gunpowder weapons because they lag behind.

This simple tournament model is certainly open to criticism. To begin with, the rulers are either bellicose, or they do not fight at all, either because they face no opposition or because they sit on the sidelines. The model does not generate more complex patterns of arming and fighting, as a repeated game might. ${ }^{29}$ But that simple pattern does describe many rulers in the early modern world. Second, because the model pits only two rulers together at any one time, it glosses over the knotty problem of alliances. Yet that too is not as great a problem as it might seem. The underlying tournament model can be extended to more than two rulers, and when it is, the insights remain the same. What in fact matters is that there are two who are willing to fight rather than just one; having more than two is unimportant. ${ }^{30}$ As for alliances, sometimes they were determined well in advance of any hostilities and confirmed by a marriage. Those it would be reasonable to treat as exogenous. The other alliances could simply be considered another means of mobilizing resources, which leaves the model unchanged so long as the average variable cost remains constant.

One final problem concerns the average variable costs $c_{i}$. These costs, which are political, cannot be observed directly. But tax rebellions, or elite opposition or defections when resources were mobilized for war would be evidence that they were high. So too would low tax levels in wartime. The reason is that in the equilibrium with war, the ratio $c_{2} / c_{1}$ of the political costs the two rulers face will (from equation 3) simply equal the inverse ratio $z_{1} / z_{2}$ of the resources they mobilize.

Perdue, China. In the nineteenth century, firearms became much more effective against nomads (Headrick, Power, pp. 281-84).

${ }^{29}$ See, for example, Jackson and Morelli, "Strategic Militarization."

${ }^{30}$ As Fullerton and McAfee show, that someone designing such a tournament can attain any level of $Z$ (and hence any expected value of innovation) at lowest cost by with only two contestants. 
Tax revenues were usually the biggest component of the resources $z_{i}$ that were mobilized for war; conscription and revenues from the ruler's possessions contributed much less in most cases. So if two rulers were fighting one another, the one with lower tax revenues would have a higher average variable cost $c_{i}{ }^{31}$ And even if rulers were not fighting one another, a higher average variable cost would, from equation 3 , imply lower taxes in wartime, although the lower taxes could also result from a less valuable prize or from differences in an enemy's average variable cost.

\section{WHERE IN EARLY MODERN EURASIA WILL THE GUNPOWDER TECHNOLOGY BE ADVANCED?}

Despite its simplicity, the tournament model does make useful predictions about when there will be war and when there will be advances in military technology, in particular the gunpowder technology. We will have war if inequality 2 holds - in other words, when the value of the prize is higher, when opponents' costs $c_{i}$ are similar, and when fixed costs $b$ are smaller. Opponents' costs will be similar if rival countries are of roughly the same size and face similar resistance to tax levies or conscription. The fixed costs will be small if setting up an army, a navy, or a fiscal system does not entail heavy expenses. That would certainly be the case if some of the fixed costs are sunk because a tax bureaucracy was already in place, naval dockyards had already been built, or a system had already been established for drafting soldiers, commandeering ships, or supplying provisions. The fixed costs would likely be modest too if the two rulers' realms lay near one another, for fighting a distant country would entail setting up a big invasion force. War will persist if the inequality holds for successive generations of rulers.

Without war, there will be no learning by doing and no improvement in military technology. If the fighting halts, so will advances in military technology, and the resources mobilized $z_{i}$ will decline too. War will be likely to stop if the fixed costs rise, or if a ruler annihilates his opponents and conquers their realms. His successors will then have no nearby rivals, and their only potential adversaries will be further away and so entail larger fixed costs. It will simply not be worth fighting them.

Continued war, which is guaranteed by inequality 2 , is, however, only a necessary condition for sustained productivity growth with the

\footnotetext{
${ }^{31}$ Of course if the difference between their average variable costs was too large, then the two would not go to war, because inequality 2 would fail to hold.
} 
gunpowder technology. It is not sufficient. For that, as we know, three other conditions must hold as well. First, the resources $Z$ spent on war must be large, for otherwise there will be little learning by doing even though the rulers are in the equilibrium with war. Since $Z=P / C$ in the equilibrium with war, a sizeable $Z$ requires a prize $P$ that is large relative to the sum $C$ of the average variable costs of the two rulers.

Second, the warring rulers must use the gunpowder technology heavily. If not, learning by doing with the technology will be minimal. Rulers who do not employ the gunpowder technology because it is ineffective against their enemies will not advance it, and those who adopt it only part of the time will improve it only modestly.

Third, the rulers must be able to acquire the latest innovations in the gunpowder technology at low cost. If not, they will lag behind leaders who have or can get the cutting-edge technology easily. The technological gap between the leaders and the laggards will widen over time if successive rulers spurn the gunpowder technology or warfare in general. If one of laggards suddenly goes to war and faces an enemy against whom the gunpowder technology is effective, then he will try to import it from the technological leaders. If he can import it quickly, he will catch up, and if his political costs $c_{i}$ are low, he will stand a good chance of defeating his opponent. But if there are obstacles to acquiring the gunpowder technology, then the gap between the leaders and laggards will persist, and it will grow even larger if the limits to knowledge shift.

These three additional conditions are necessary for advances with the gunpowder technology, and together with inequality 2 they are sufficient. When and where do all four of them hold? Let us start with the second of the additional conditions - that the rulers use the gunpowder technology heavily. It clearly applies to Western Europe and Japan, but it fails in China, for 95 percent of the time China was engaged in war involving nomads against whom firearms long remained impotent (Table 2). In confrontations with nomads, the older technology of mounted archers was more effective. The Western Europeans, by contrast, fought no wars against nomads.

Not that China shunned the gunpowder technology altogether. It in fact gained in appeal in the early seventeenth century, when an arms race began to develop in East Asia. As the Ming dynasty, beset by rebellions and under attack by the Manchus, fell into decline, its troops fought and defended besieged cities with muskets and artillery. Their opponents replied in kind. But when the Ming dynasty collapsed and China was unified under the Qing dynasty (1644-1911), the nomads 
TABLE 2

FREQUENCY OF FOREIGN WAR IN CHINA AND EUROPE, 1500-1799

\begin{tabular}{lc}
\hline \hline Country & $\begin{array}{c}\text { Percent of Time Country is at War Against } \\
\text { Foreign Enemies, 1500-1799 }\end{array}$ \\
\hline China & \\
All wars & 56 \\
Excluding wars against nomads & 3 \\
France & 52 \\
England/Great Britain & 53 \\
Spain & 81 \\
Austrian dominions & 24
\end{tabular}

Notes: Excluding wars against nomads does not change the figures for the western European countries because they did not fight wars against nomads. The data for this table were collected by Margaret Chen, except for those for China, which were kindly furnished by James Kung. Chen also collected figures for China from Chinese sources, and her numbers were similar to Kung's.

Sources: Clodfelter, Warfare; Wright, Study; Stearns, Encyclopedia; and Kung (personal communication of the figures for China).

remained the new dynasty's major enemy well into the eighteenth century, and against them the gunpowder technology was still ineffective because it continued to strain supply lines to the breaking point. ${ }^{32}$

Russia, the Ottoman Empire, and the various powers waging war in India faced similar problems with enemies who kept them from focusing on the gunpowder technology. Until the middle of the seventeenth century, the Russians' major land enemy was nomadic Tatars. Firearms were of some use against them, particularly if deployed from behind fortified lines, but cavalry armed with bows and sabers was the major weapon, as in China. The Ottomans emphasized cavalry too, because much of their conflict involved frontier skirmishes and raiding. Even in the eighteenth century over 77 percent of their army was cavalry, versus under 27 percent in France. As for India, until the eighteenth century, warfare there too made heavy use of cavalry.

In addition, both the Ottomans and Russians had to funnel resources into another ancient technology with limited potential for improvement via learning by doing-galley warfare. Galleys, which dated back to classical times, were ideally suited to amphibious warfare in the light winds of the Mediterranean. They were also important for Russia on the Black Sea and the Baltic. Galleys did grow more effective in the Middle Ages, and in the early sixteenth century they acquired ordnance that made it possible to smash ship hulls. But then the limits to improving this aged technology were reached. Only a few guns could be

\footnotetext{
${ }^{32}$ Needham, Science, vol. 5, part 7: pp. 398-407; Franke, "Siege”; Atwell, "T'ai-ch'ang"; Lorge War; and Perdue, China.
} 
added without taxing the oarsmen; with little room to store water for the oarsmen, the galleys' range was severely restricted; and they were vulnerable to heavily armed sailing ships. ${ }^{33}$

In short, the requirement that rulers rely almost exclusively on the gunpowder technology would work against innovation in the Ottoman Empire. It would lead to the same prediction for India before the eighteenth century, for China, except in the waning days of the Ming dynasty, and for Russia, at least before the late seventeenth century, when the Tatars ceased being a major threat. Japan and Western Europe, by contrast, would be more fertile ground for innovation.

Japan, however, eventually ran afoul of inequality 2, which predicts that war will stop if one ruler annihilates his opponents and conquers their realms. Without war, learning by doing stops, and so do advances in military technology. The resources mobilized $z_{i}$ decline too. Such an outcome never occurred in early modern Europe, which was always torn by conflict. But that is precisely what took place in Japan when it was unified under the Tokagawa Shogunate (1603-1867).

Japan had suffered through generations of devastating civil war until three victorious warlords finally unified the fragmented country under what became the rule of the Tokugawa Shoguns. By crushing opposition and rewarding loyalty, the Tokugawa then fashioned a regime that eliminated internal strife. Peace made the populace better off, but it left the Shogun with no one else to fight. In terms of our model, it was as though Japan's ruler was in a tournament with no other contestants. He would have had no reason to devote resources to war or to advance the gunpowder technology, which had been heavily used in Japan ever since firearms were introduced in 1543. One might of course wonder why he or the warlords who united the country did not turn to foreign conquests once they had vanquished their domestic enemies. One of the warlords, Toyotomi Hideyoshi, actually did try to invade Korea (and via Korea, China) in 1592 and 1597, but failed, because he "lacked the resources" needed to carry out such an operation-in particular, a large navy. Other Japanese leaders were "unenthusiastic" about the operation and "quickly" withdrew from Korea after Hideyoshi died. They seemed to realize that an invasion without adequate resources was unrealistic. They knew, in other words, that successful military competition against foreign powers entailed a large fixed cost

\footnotetext{
${ }^{33}$ For this and the preceding paragraph, see Agoston, Guns, pp. 191, 202-03; Esper, "Military"; Glete, Navies, pp. 114-15, 139-46, 310, 706-12; Gommans, Mughal; Gommans and Kolff, Warfare; Guilmartin, "Ideology" and Galleons, pp. 106-25; Hellie, Enserfment; Lynn, Giant, pp. 528-29; McNeill, Steppe; Parry and Yapp, War; Paul, "Military Revolution"; and Pryor, Geography.
} 
(relative to the size of the prize), including the expense of building a powerful navy. That fixed cost — the $b$ in the tournament model - ruled out the possibility of foreign war and thus halted improvements to the gunpowder technology. ${ }^{34}$

As in Tokugawa Japan, inequality 2 would have also discouraged China from fighting distant wars in which the gunpowder technology might have been more useful than it was against nomads. For much of its history, China was a large unified empire and much bigger than neighboring states. The emperors (and the officials who advised them) would therefore have found themselves in a situation akin to that of the Tokugawa Shoguns: warfare abroad (including invading Japan) would have required building an effective navy or fighting distant land battles. That would have meant paying a prohibitively high fixed cost $b$, which would have made such wars unattractive.

What about the two other conditions for improving the gunpowder technology: that the ratio $P / C$ of the value of prize to the sum of the average variable costs be high, and that rulers be able to acquire the latest innovations at low cost? The requirement that $P / C$ be high clearly handicapped the Ottoman Empire in the eighteenth century. The Ottomans were fighting European states so they were contending for the same prize $P$, but their tax revenues were lower than in eighteenthcentury Europe. They collected less than the median for major European powers, less than what one of their major opponents, the Austrians raised, and less than what their other chief enemy, the Russians, mobilized, at least after $1750 .{ }^{35}$ It follows that the Ottomans had a higher average variable cost of mobilizing resources than in Europe and that they were unlikely to be the ones advancing the gunpowder technology. Their high cost of mobilizing resources would also imply (from expression 5) that they had little chance of defeating European rulers in the eighteenth century even if they imported the latest weapons and tactics.

As for the European rulers, their average variable costs of mobilizing resources were not only lower than in the Ottoman Empire (at least after 1700), but likely lower than in China too. The evidence comes from capita tax rates in wartime, which were much higher in Europe than in China (Table 3). Although the difference could simply reflect a less valuable prize in China or the nature of China's enemies, it is bolstered

\footnotetext{
${ }^{34}$ Smith, "Land Tax"; Reischauer, Fairbank, and Craig, History, vol. 1: pp. 614-15; Berry, Hideyoshi, pp. 207-17, "Presidential Address," and "Public Peace," pp. 207-17; Brown, Central Authority; Parker, Military Revolution, pp. 140-43; Guilmartin, Galleons, pp. 182-90; and Chase, Firearms, pp. 175-96.

${ }^{35}$ Pamuk and Karaman, "Ottoman."
} 
TABLE 3

ANNUAL PER CAPITA TAXATION IN CHINA, ENGLAND, AND FRANCE, 1578 AND 1776 (in grams of silver)

\begin{tabular}{llrr}
\hline \hline & & 1578 & 1776 \\
\hline China & Total & 6.09 & 8.08 \\
China & Portion under central government control & 3.56 & 7.03 \\
England & Portion under central government control & 10.47 & 180.06 \\
France & Portion under central government control & 16.65 & 61.11 \\
\hline
\end{tabular}

Note: The figures for England and France are decennial averages. For China, they are upper bound estimates that involve the following assumptions: the population is 175 million in 1578 and 259 million in 1776; the grain levy in 1578 is converted to silver at 1 shi equals 0.6 taels of silver; the service levy in 1578 is worth 10 million taels per year; the portion of taxes under central government control in 1578 includes taxes sent to Beijing or Nanjing, plus 25 percent of the service levy; 87 percent of the taxes are under central government control in 1776. China was at war in 1578 and 1776, which might have raised tax levels. For the sake of comparison, England was at war throughout the 1570s and seven years out of ten in the 1770s; France fought three years of ten in the 1570s and five years of out ten in the 1770s.

Source: For France, see Hoffman and Norberg, Fiscal Crises, pp. 238-39; for England, see the European State Finance Data Base that Richard Bonney has assembled (http://www.le.ac.uk/hi/bon/ESFDB/dir.html ), data Mark Dincecco has posted at the Global Price and Income Group website ( http://gpih.ucdavis.edu/ ) and explained in Dincecco, "Fiscal Centralization," and population figures from Wrigley and Schofield, Population History, table A3.1; for China, see Huang, "Ming Fiscal"; Myers and Wang, "Economic Developments"; Liu, "Nexus of Power"; and the Global Price and Income History Group website for units, silver equivalents, and prices of grain in China.

by claims that tax revenue in China were in fact constrained by the threat of revolt and by elites who could more easily siphon off tax revenue in larger empire. ${ }^{36}$ Another sign that the average variable cost was low in Europe is that taxes were high relative to GDP, at least in the eighteenth century, when we can make such comparisons for France and England. By then, France was spending 5 to 10 percent of its GDP on military resources, and Great Britain even more - perhaps as much as 28 percent. ${ }^{37}$ For countries that were still poor by modern standards, these figures are quite high. For comparison, at the end of the Cold War, the United States was devoting 5 percent of its GDP to the military, and the USSR perhaps 10 percent. ${ }^{3}$

Like Europe, Japan before the Tokugawa Shogunate might have also faced low average variable costs. The evidence is indirect. The armies Japanese warlords raised were big relative to the population, but that would be what one would expect in wartime when $P / C$ was large. ${ }^{39}$

\footnotetext{
${ }^{36}$ Huang, "Military Expenditures" and "Ming Fiscal"; Sng, "Size"; and Brandt, Ma, and Rawski, "From Divergence."

${ }^{37}$ Kennedy, Rise, table 2; and Mathias and O'Brien, "Taxation," table 5. French military expenditures are assumed to range from 45 to 85 percent of tax revenues.

${ }^{38}$ Brzoska, "Military Expenditures," table 3.

${ }^{39}$ Finer, History, vol. 3, p. 1088.
} 
By the eighteenth century, the Russians too likely had a low average variable cost too and a high value for $P / C$. They were by then fighting the Western Europeans for the same prize, and although their per capita tax revenues were still lower than in the west, the czars - thanks to the reforms of Peter the Great (1682-1725) - could draft serfs into the military, cutting the average variable costs of fielding a military force. ${ }^{40}$ By contrast, western leaders had to wait for the wars of the French Revolution to conscript troops on that scale.

Finally, India's leaders were hobbled by high average costs of mobilizing resources and by a lower value of the prize they were fighting for, all of which reduced their $P / C$ ratio. The Indian case is in fact a telling one. In the eighteenth century, the subcontinent was convulsed by virtually constant warfare among the leaders and states that arose as the Mughal Empire disintegrated. The unremitting hostilities imply that inequality 2 was satisfied, and the armies were fighting with gunpowder weapons and could easily have acquired leading innovations from one another in what was an active market for military goods and services. ${ }^{41}$ But the one remaining condition required for advancing the gunpowder technology - that $P / C$ be high — failed to hold.

On the one hand, political costs $C$ of mobilizing resources were high. Data on tax revenues for India are lacking, but it is clear that the new states that emerged on the subcontinent were struggling to gain control of resources that remained in local hands. ${ }^{42}$ In addition, the value of the prize $P$ was reduced by conflict within powerful Indian families over succession to a throne or rights to rule. ${ }^{43}$ Strife of this sort, which after the late Middle Ages was rarer in Europe, cut the value of the prize for victors in India, by raising the odds that a prince or other ruler would be unable to enjoy the fruits of winning. The prize was still valuable enough to get the rulers to fight, but not big enough relative to the average variable costs of fighting to get them to mobilize a large amount of resources $Z$. Since they were not raising many resources, the model would predict that their wars would generate little or no innovation.

The Indian case shows why unending warfare and highly developed markets for military goods were not enough to obtain advances in the use of gunpowder. If they had been enough, then eighteenth-century

\footnotetext{
${ }^{40}$ Hellie, Enserfment; and Pintner, "Burden."

${ }^{41}$ Kolff, Naukar; Gommans and Kolff, Warfare; and Gommans, Mughal. Although the Mughal Empire did use gunpowder weapons, it was more reliant on cavalry than the Europeans.

${ }^{42}$ Barua, "Military Developments"; Stein, "State Formation"; Washbrook, "Progress"; and Alam and Subrahmanyam, "L'état moghol."

${ }^{43}$ Gommans, Mughal.
} 
India should in fact have been an innovator, not a laggard. Our model, by contrast, predicts the opposite, because with high political costs and strife over rights to rule, the Indian rulers would in equilibrium utilize small amounts of military resources and thus fail to innovate. The model can also help explain why the East India Company became a dominant military power in India. It simply had lower average variable costs of using the military and thus was willing to mobilize more military resources in equilibrium. Not only could it draw on its own financial system to fund its military ventures, but it had also gotten control of the wealthy Ganges plain in northwestern India and won support for higher taxes there by offering elites a land market in return for higher levies. Elite cooperation and more wealth to tax would mean a lower average cost $c_{i}$ and, from expression 5, a greater chance of winning wars. It would be no surprise then that the company conquered much of the subcontinent, simply by hiring away the best officers and their troops. ${ }^{44}$

The only remaining condition is that rulers be able to acquire innovations at low cost. The barriers to doing so are clear. In the early modern world, embargos would not have been the major obstacle, since enforcement was difficult. But distance alone hampered the diffusion of the latest skills, weapons, and tactical innovations, even if mercenaries and weapons makers were willing to work for foreign masters. Technological gaps could then have increased if learning by doing persisted in one part of Eurasia and stopped in another. All rulers potentially could have advanced the gunpowder technology, but if some fell behind, catching up would have been difficult.

Some parts of the technology, after all, were just hard to transfer, which would have widened the gaps between laggards and leaders. The reason was that they involved a number of complementary skills or reforms, and rulers had to acquire the whole package if they wanted the innovation. One of the improvements to French artillery in the eighteenth century, for instance, was a shift to manufacturing them by boring a solid casting instead of using a mould with a hollow core. Boring made cannons more accurate and cut the number rejected in initial testing. But adopting the technique required careful training and supervision of whole teams of skilled workers. The Swiss cannon founder who perfected the process complained that if business declined and some of his employees departed, he would have a hard time finding and training replacements when demand picked up again. And so, when

\footnotetext{
${ }^{44}$ Alavi, Sepoys; Gommans and Kolff, Warfare; Cooper, Campaigns; Gommans, Mughal; and T. Roy, "British India."
} 
he was asked to export the process to France's ally, Spain, he contracted to import a whole group of skilled workers and even obtained the right to impose heavy penalties on any of them who quit. ${ }^{45}$ Hiring the cannon founder alone was thus insufficient. The king of Spain needed all the supporting skills, or else he had to wait until a skilled team could be assembled and whipped into shape. Transferring the innovations would have been even slower if they depended on complementary skills, such as navigation or metalworking, that were scarce in the civilian economy.

Gunpowder innovations would spread most easily, we would therefore expect, when enemy powers were small and near one another and when military goods, services, and ideas could move between them with relative freedom. That was the case in India, and perhaps in Japan before the Tokugawa Shogunate as well, since the battling Japanese warlords were close enough to one another to at least copy what worked. And it was certainly the case in Western Europe.

Western Europe is also the only part of Eurasia that satisfies all the other conditions required for advancing the gunpowder technology, and it does so throughout the entire early modern period. No other Eurasian powers can meet that standard. The model would therefore predict that Western Europe would be a leader in advancing the gunpowder technology. The other Eurasian powers would have lagged behind. Could they have caught up by importing European innovations when needed? They would all have had an incentive to buy the latest military technology from Western Europe if it was more effective militarily, and the Europeans did in fact export their arms and expertise to places as far away as China. ${ }^{46}$ But wholesale transfer of the cutting-edge technology would have been hampered by distance alone in South or East Asia. If it was difficult to move a whole team of cannon makers from France to Spain, how much harder would it have been to get them to India or China? The obstacles would have been much higher, because of the risks of ocean travel and the difficulties of getting Europeans to settle in an alien place.

Russia and the Ottoman Empire would have a somewhat easier time of it, since they were closer to Western Europe. Yet even with the imports, we would predict that anemic tax revenues would keep the Ottomans from defeating the Europeans after 1700. The Russians, by contrast, could be expected to do much better, at least after the late seventeenth century. Not only could they import the technology more easily than

\footnotetext{
${ }^{45}$ Alder, Engineering, pp. 39-46; and Minost, "Maritz."

${ }^{46}$ Hoffman, "Prices."
} 
distant Asian powers, but they could now focus on fighting with gunpowder weapons and mobilize enormous resources by drafting serfs.

\section{TESTING THE MODEL'S IMPLICATIONS IN EARLY MODERN EURASIA}

We can test the model's implications for early modern Eurasia. If we begin with Western Europe, we would expect to see innovation and productivity growth in the military sector. That certainly fits the literature on the military revolution, but there is also quantitative evidence supporting this prediction too, for we can measure the rate at which the productivity of the technology was increasing. The yardsticks used underestimate the productivity growth, because they fail to capture advances in tactics or provisioning that were an integral part of the gunpowder technology. They also have trouble with naval warfare, where Western Europe's lead was perhaps greatest. The reason is that warships had a variety of different goals, which varied over time. Firepower dominated the eighteenth century, but speed, range, and an ability to fight in inclement weather were also important, particularly in wars of economic attrition that were the focus of much early modern naval warfare. ${ }^{47}$

Yet despite all these difficulties, the evidence that military productivity was advancing in early modern Europe is clear. Suppose, for example, that we ignore the other goals navies pursued and take firepower, measure by the weight of the shot, as our sole yardstick of naval output, which we can divide by shipboard labor and capital to get an index of total factor productivity. In the English navy, this index was rising at a rate of 0.4 percent per year between 1588 and 1680, a period when firepower was gaining in importance. ${ }^{48}$ Such a rapid growth was virtually unheard of in preindustrial economies, where total productivity was typically increasing at 0.1 percent per year or less in major sectors of the economy, if it grew at all. ${ }^{49}$

\footnotetext{
${ }^{47}$ Guilmartin, Gunpowder, pp. 253-254 and "Guns"; and Glete, Navies, pp. 58-61.

${ }^{48}$ Capital is computed from displacement, and labor from crew sizes for the English navy, using Martin and Parker, Armada; and Glete, Navies, pp. 186, 195, 205. Factor shares (0.496 for capital and 0.503 for labor) come from 1744 construction and crew labor costs in Boudriot and Berti, Les vaisseaux, pp. 146-52. For firepower, see Glete, Navies; Guilmartin, Galleons; and Martin and Parker, Armada, pp. 33-36.

${ }^{49}$ For examples, see Hoffman, Growth; and Clark, Farewell. One might argue that the English navy was simply specializing in firepower at the expense of speed or range-in other words, that it was moving along a frontier of output possibilities while productivity remained constant. But by the late 1500 s it had already begun to emphasize bombardment as an alternative to the boarding that had been the customary goal in naval battles, and the 1588 data
} 
Nor was productivity growth limited to naval warfare. On land, the effective firing rate per French infantryman jumped by a factor of 6 or more between 1600 and 1750 , as bayonets made it possible to replace pike men and matchlocks were supplanted by flintlocks with ramrods and paper cartridges. The higher firing rate translated into labor productivity growth of 1.5 percent per year, which rivals overall labor productivity growth rates in modern economies and far exceeds what one would expect for preindustrial economies. ${ }^{50}$

Still another sign of rapid productivity growth was the falling price of weapons. The prices of cannons, muskets, and pistols tumbled relative to the price of other manufactured goods and relative to the cost of the relevant factors of production. Using the cost function dual, we can estimate productivity for weapons manufacturing in early modern France and England. The median total factor productivity growth rate over periods ranging from the late fourteenth century to the late eighteenth century turns out to have been 0.6 percent per year, a rapid pace even at the outset of the Industrial Revolution. ${ }^{51}$

What about the model's implications for the rest of early modern Eurasia? Although we lack similar figures for productivity, we can test the predictions against the historical record. If we begin with Japan, the model predicts improvements to the gunpowder technology until the Tokugawa Shogunate gained power in the early seventeenth century, when warfare and innovation should have stopped and tax collections should have tapered off.

Those predictions match the historical record. Before the Tokugawa, the Japanese had discovered-some twenty years earlier than Europeans - the key tactical innovation of volley fire that allowed infantry soldiers with slow-loading muskets to maintain a nearly continuous round of fire. With the Tokugawa, war stopped and so did that sort of innovation. ${ }^{52}$ And over time, tax revenues declined as fraction of agricultural output. ${ }^{53}$ A cultural explanation cannot account for this sudden change, for Japanese continued to have a strong attachment to martial values. One might fear that this line of argument simply repeats the story of how the Tokugawa Shoguns banished guns. But in fact, the

in fact come from ships that were already specialized in firepower- the heavily armed flotilla that defeated the Spanish Armada.

${ }^{50}$ Hoffman, "Prices," Table 3.

${ }^{51}$ Ibid. An alternative calculation yields an even higher median rate of 1.1 percent per year.

${ }^{52}$ Parker, Military Revolution, pp. 18-19, 140-143; Chase, Firearms, pp. 175-196; and Berry "Presidential Address."

${ }^{53}$ Smith, "Land Tax." 
shoguns did not ban firearms. Although they disarmed the population, they kept their own guns and required them for lords too. ${ }^{54}$

Historical evidence also confirms the model's implications for China and eighteenth-century India. Both would have been expected to lag behind Western Europe in developing the gunpowder technology, even though China was the birthplace of firearms and India would have been fertile ground for advances in gunpowder technology if the argument about competition were correct. Both should also have tried to import weapons and expertise from Europe when the gunpowder technology proved useful.

That is exactly what happened. In China, officials recognized that European weapons were superior, and they sought designs and expertise from the Portuguese or the Jesuits in both the Ming and the Qing dynasties. ${ }^{55}$ Military leaders in eighteenth-century India followed much the same path. They readily adopted new weapons and tactics in their unending wars, but they did not break new ground in their use. The innovations, by and large, came from Western Europe with renegade experts, mercenary officers, and imports of weapons. ${ }^{56}$

The model implies that Russia and the Ottoman Empire would also have been less likely to advance the gunpowder technology and that both would have imported weapons and military expertise from Western Europe, up until the eighteenth century. Then their paths would have diverged. High political costs $c_{i}$ would have made the Ottomans drop further back and cut their odds of winning wars, particularly against western powers. The reverse would have happened for the Russians.

In fact, military historians argue that the Ottomans fell behind Western Europe in the late seventeenth century, particularly in field warfare. Although the Ottomans had a large artillery industry, they imported expertise from Western Europe. By the eighteenth century, they dropped from the ranks of the great powers in Europe and were

\footnotetext{
${ }^{54}$ For the source of the story (Noel Perrin's Giving up the Gun) and a review that sets the facts straight, see Totman, "Review."

${ }^{55}$ Josson and Willaert, Correspondance de Verbiest; Needham, Science, vol. 5, part 6; Spence, To Change China, pp. 15, 29; Franke, "Siege"; Väth, Johann Adam Schall von Bell, pp. 111-15; Waley-Cohen, "China"; Lorge, War, pp. 125-28; and Li, "Late Ming Military Reform."

${ }^{56}$ Kolff, Naukar; Gommans and Kolff, Warfare; Gommans, Mughal; and K. Roy, "Hybrid Military Establishment." Even defenders of Indian military prowess admit that the advances with the gun powder technology by and large came from the West. See Subrahmanyam, "Kagemusha"; Barua, "Military Developments"; Alavi, Sepoys, pp. 24-25; Cooper, Campaigns, pp. 31-32, 42-44, 289-94; and Parthasarathi, Why Europe, pp. 206-13.
} 
more likely to lose wars. ${ }^{57}$ Russia, by contrast, joined the great powers in the eighteenth century, after importing western officers, shipwrights, cannon founders, and military architects. It increasingly began to win wars against Western European powers. ${ }^{58}$

The divergence between Russia and the Ottoman Empire is difficult to square with the argument that wars alone led to gunpowder innovations because both were frequently engaged in conflicts. That argument also fails to explain why all the wars in war-torn eighteenth-century India failed to advance the gunpowder technology. The tournament model can. It can also account for why China lagged behind, even though it was the birthplace of the gunpowder technology, and why Japan suddenly stopped improving the gunpowder technology, a shift that cannot be reconciled with a cultural argument. And the model also fits Eurasian evidence about military victories, trends in taxation, and the flow of military goods and services.

\section{CONCLUSION}

The tournament model of Europe's wars yields a deeper understanding of why Europeans pushed the gunpowder technology of firearms, fortifications, and armed ships further than anyone else. Exogenous political and military conditions drove the rulers of Western Europe's major powers to raise taxes and to spend heavily on this technology in fighting unending wars. The result was sustained innovation via learning by doing, all before the Industrial Revolution.

Elsewhere, political and military conditions blocked such an outcome. In Japan, unification under the Tokugawa Shogunate snuffed out a similar tournament and removed incentives to funnel resources into the gunpowder technology. The story was similar in China, for it too, most of the time, was a large, unified empire. Furthermore, the gunpowder technology was not effective against its major enemy, nomads from the north. The technology was of little use either in Russia's early wars, or against some of the Ottoman Empire's adversaries. In addition, by the eighteenth century, the Ottoman emperors faced heavy political obstacles

\footnotetext{
${ }^{57}$ Levy, War; Murphey, "Ottoman Attitude"; and Agoston, Guns, pp. 10-12, 193-94, 201. The Ottomans lost 30 percent of 23 wars in the years 1500-1699 and 56 percent of nine wars in 1700-1799 ( $p=0.09$, one-sided).

${ }^{58}$ Cipolla, Guns; Hellie, Enserfement; Levy, War; Pintner, "Burden"; Anisimov, Reforms; Paul, "Military Revolution"; and Kotilaine, "Defense." Russia did develop an arms industry during the seventeenth and eighteenth centuries, but arms imports continued up to the 1780s. Russia lost 36 percent of 11 wars in $1500-1699$ and 12 percent of 17 wars in 1700-1799 $(p=0.06$, one-sided $)$.
} 
to raising taxes. So did the leaders whose forces battled in unending wars in eighteenth-century India.

The implication, according to the model, is that all of these parts of Eurasia would fall behind Western Europe in developing the gunpowder technology, and that the gap would grow over time, particularly in countries far from the leaders in Western Europe, because distance would slow the transfer of innovations, particularly if packages of complementary skills were involved. Both quantitative and qualitative evidence bears out this and the other predictions the model makes and argues against alternative explanations for Europe's dominance of the gunpowder technology. The argument about competition, for example, cannot explain why all the wars in eighteenth-century India failed to make it a center of military innovation.

Europe's lead was not foreordained. Learning by doing would have been possible anywhere before the Industrial Revolution, provided that the exogenous political and military conditions were right. If the Mongols, for example, had not conquered China, then it might have remained divided, and the successors to the southern Song emperors might have had more of an incentive to funnel resources into the gunpowder technology. China, the birthplace of gunpowder, might not have fallen behind.

But Europeans ended up dominating this technology, which allowed them to wage war at a distance. They were not posting huge infantry armies abroad, at least before the nineteenth century. But they could dispatch ships armed with cannons to prey upon trade in places as far away as Southeast Asia, and for protection, ship maintenance, and essential supplies of water and fresh food, the ships could rely upon European-style fortresses, which, when built in Asia or the Americas, could be defended with a relatively small force. The fortresses thus complemented the naval forces and allowed the Europeans to hold critical trading posts and to protect what land they conquered without sending large numbers of officers and men abroad, an expensive undertaking given the high mortality rates during long voyages. And further technological innovation in the nineteenth century (which a variant of the model can explain) made it possible to extend the conquests and create colonial empires. ${ }^{59}$

${ }^{59}$ Headrick, Tools and Power. 


\section{REFERENCES}

Agoston, G. Guns for the Sultan: Military Power and the Weapons Industry in the Ottoman Empire. Cambridge: Cambridge University Press, 2005.

Alam, M., and S. Subrahmanyam. "L'état moghol et sa fiscalité (XVIe-XVIIIe siècles)." Annales: Histoire, Sciences Sociales 49 (1994): 189-217.

Alavi, S. The Sepoys and the Company: Tradition and Transition in Northern India, 1770-1830. Oxford: Oxford University Press, 1995.

Alder, K. Engineering the Revolution: Arms and Enlightenment in France, 1763-1815. Princeton, NJ: Princeton University Press, 1997.

Anisimov, E. V. The Reforms of Peter the Great: Progress through Coercion in Russia. London: M. E. Sharpe, 1993.

Atwell, W. "The T'ai-ch'ang, T'ien-ch'i, and Ch'ung-chen Reigns, 1620-1644." In The Cambridge History of China, Volume 8, edited by J. K. Fairbank and D. C. Twitchett, 585-640. Cambridge: Cambridge University Press, 1988.

Barfield, T. J. The Perilous Frontier: Nomadic Empires and China. Oxford: Blackwell, 1989.

Barua, P. "Military Developments in India, 1750-1850." Journal of Military History 58, no. 4 (1994): 599-616.

Bell, D. A. The First Total War: Napoleon's Europe and the Birth of Warfare As We Know It. Boston and New York: Houghton Mifflin, 2007.

Berry, M. E. Hideyoshi. Cambridge, MA: Harvard University Press, 1982. . "Public Peace and Private Attachment: The Goals and Conduct of Power in Early Modern Japan." Journal of Japanese Studies 12, no. 2 (1986): 237-71. . "Presidential Address: Samurai Trouble: Thoughts on War and Loyalty." The Journal of Asian Studies 64, no. 4 (2005): 831-47.

Black, J. War and the World: Military Power and the Fate of Continents, 1450-2000. New Haven, CT: Yale University Press, 1998.

Bonaparte, N.-L., and I. Favé. Etudes sur le passé et l'avenir de l'artillerie. Paris: J. Dumaine, 1846-1872.

Boudriot, J., and H. Berti. Les vaisseaux de 50 et 64 canons: Etude historique 1650-1780. Paris: ANCRE, 1994.

Brandt, L., D. Ma, and T. G. Rawski. "From Divergence to Convergence: Reevaluating the History Behind China's Economic Boom.” Working Paper, Economic History Department, London School of Economics, 2011.

Brito, D. L., and M. D. Intriligator. "Conflict, War, and Redistribution." The American Political Science Review 79, no. 4 (1985): 943-57.

Brown, P. C. Central Authority and Local Autonomy in the Formation of Early Modern Japan. Stanford, CA: Stanford University Press, 1993.

Brzoska, M. "World Military Expenditures." In Handbook of Defense Economics, edited by K. Hartley and T. Sandler, 45-67. Amsterdam: Elsevier, 1995.

Chase, K. W. Firearms: A Global History to 1700. Cambridge, UK and New York: Cambridge University Press, 2003.

Cipolla, C. M. Guns, Sails, and Empires: Technological Innovation and the Early Phases of European Expansion, 1400-1700. New York: Pantheon Books, 1965.

Clark, G. A Farewell to Alms: A Brief Economic History of the World. Princeton, NJ: Princeton University Press, 2007.

Clodfelter, M. Warfare and Armed Conflicts: A Statistical Guide to Casualty and Other Figures, 1500-2000. Jefferson, NC: McFarland, 2002. 
Cooper, R. G. S. The Anglo-Maratha Campaigns and the Contest for India. Cambridge: Cambridge University Press, 2003.

Corvisier, A. et al. Histoire militaire de la France. Paris: Presses Universitaires de France, 1997.

Dincecco, M. "Fiscal Centralization, Limited Government, and Public Revenues in Europe, 1650-1913." The Journal of Economic History 69, no. 1 (2009): 48-103.

Esper, T. "Military Self-Sufficiency and Weapons Technology in Muscovite Russia." Slavic Review 28, no. 2 (1969): 185-208.

Fearon, J. D. "Rationalist Explanations for War." International Organization 49, no. 3 (1995): 379-414.

Finer, S. E. The History of Government. Oxford: Oxford University Press, 1997.

Fletcher, E., and M. Iyigun. "The Clash of Civilizations: A Cliometric Investigation." Working Paper, Institute for the Study of Labor, University of Colorado, 2010.

Franke, H. "Siege and Defense of Towns in Medieval China." In Chinese Ways in Warfare, edited by F. A. Kiernan and J. K. Fairbank, 151-201. Cambridge, MA: Harvard University Press, 1974.

Fullerton, R. L., and R. P. McAfee. "Auctioning Entry into Tournaments." The Journal of Political Economy 107, no. 3 (1999): 573-605.

Garfinkel, M. R., and S. Skaperdas. "Economics of Conflict: An Overview." In Handbook of Defense Economics, Volume 2, edited by T. Sandler and K. Hartley, 649-709. Amsterdam: Elsevier, 2007.

Glete, J. Navies and Nations: Warships, Navies, and State Building in Europe and America, 1500-1800. Stockholm: Almqvist \& Wiksell International, 1993.

Gommans, J. Mughal Warfare: Indian Frontiers and High Roads to Empire, 1500-1700. London: Taylor and Francis, 2003.

Gommans, J., and D. H. A. Kolff, eds. Warfare and Weaponry in South Asia, 1000-1800. Oxford: Oxford University Press, 2001.

Goodman, D. C. Power and Plenty: Government, Technology, and Science in Philip II's Spain. Cambridge: Cambridge University Press, 1988.

Guilmartin, J. F. Gunpowder and Galleys: Changing Technology and Mediterranean Warfare at Sea in the Sixteenth Century. Cambridge: Cambridge University Press, 1974.

."The Guns of the Santissimo Sacramento'.” Technology \& Culture 24, no. 4 (1983): 559-601.

. "Ideology and Conflict: The Wars of the Ottoman Empire, 1453-1606." Journal of Interdisciplinary History 18, no. 4 (1988): 721-47.

. Galleons and Galleys. London: Cassell, 2002.

Hale, J. R. War and Society in Renaissance Europe, 1450-1620. Baltimore, MD: Johns Hopkins University Press, 1985.

Hall, B. S. Weapons and Warfare in Renaissance Europe: Gunpowder, Technology, and Tactics. Baltimore, MD: Johns Hopkins University Press, 1997.

Harding, R. Amphibious Warfare in the Eighteenth Century: The British Expedition to the West Indies, 1740-1742. Woodbridge, UK: The Royal Historical Society, 1991.

Headrick, D. R. The Tools of Empire: Technology and European Imperialism in the Nineteenth Century. New York and Oxford: Oxford University Press, 1981.

. Power over Peoples: Technology, Environments, and Western Imperialism, 1400 to the Present. Princeton, NJ: Princeton University Press, 2010.

Hellie, R. Enserfment and Military Change in Muscovy. Chicago: University of Chicago Press, 1971. 
Hoffman, P. T. Growth in a Traditional Society. Princeton, NJ: Princeton University Press, 1996.

."The Politics and Economics of Europe's Comparative Advantage in Violence."

Global Price and Income History Working Paper No. 13, December 2008.

"Prices, the Military Revolution, and Western Europe's Comparative Advantage

in Violence." Economic History Review 64, S1 (2011): 39-59.

."Why Was It Europeans Who Conquered the World?" California Institute of Technology, Social Science Working Paper 1344, March 2012.

Hoffman, P. T., and Kathryn Norberg, eds. Fiscal Crises, Liberty, and Representative Government, 1450-1789. Stanford, CA: Stanford University Press, 1994.

Hoffman, P. T., and J.-L. Rosenthal. "The Political Economy of Warfare and Taxation in Early Modern Europe: Historical Lessons for Economic Development." In The Frontiers of the New Institutional Economics, edited by J. N. Drobak and J. V. C. N. Nye, 31-55. San Diego, CA: Academic Press, 1997.

Huang, R. "Military Expenditures in Sixteenth-Century China." Oriens Extremus 17 (1970): 39-62.

"The Ming Fiscal Administration." The Cambridge History of China, Volume 8, edited by J. K. Fairbank and D. C. Twitchett, 106-71. Cambridge: Cambridge University Press, 1998.

Jackson, M. O., and M. Morelli. "Political Bias and War." American Economic Review 97, no. 4 (2007): 1353-73.

."Strategic Militarization, Deterrence, and Wars." Quarterly Journal of Political Science 4, no. 4 (2009): 279-313.

" "The Reasons for Wars: An Updated Survey." In Handbook on the Political Economy of War, edited by C. Coyne and R. Mathers, Part 3. New York: Elgar, 2011.

Josson, H. and L. Willaert, eds. Correspondance de Ferdinand Verbiest de la compagnie de Jésus (1623-1688) Directeur de l'obervatoire de Pékin. Brussels: Palais des académies, 1938.

Kennedy, P. M. The Rise and Fall of the Great Powers: Economic Change and Military Conflict from 1500 to 2000. New York: Random House, 1987.

Kolff, D. H. A. Naukar, Rajput and Sepoy: The Ethnohistory of the Military Labour Market in Hindustan, 1450-1850. Cambridge: Cambridge University Press, 1990.

Kotilaine, J. T. "In Defense of the Realm: Russian Arms Trade and Production in the Seventeenth and Early Eighteenth Century." The Military and Society in Russia: 1450-1917, edited by Eric Lohr and Marshall Poe, 94-95. Leiden: Brill, 2002.

Kung, James. Personal communication of data on frequency of Chinese wars involving nomads, December 9, 2010.

La Noue, F. d. Discours politiques et militaires du seigneur de la Noue. Basel: L'imprimerie de F. Forest, 1587.

Lavery, B. The Ship of the Line. London: Naval Institute Press, 1983-1984.

Levy, J. S. War in the Modern Great Power System, 1945-1975. Lexington: University Press of Kentucky, 1983.

Li, B. "The Late Ming Military Reform under the Shadow of Financial Crisis." Utrecht, World Economic History Conference, 2009.

Liu, G. W. "The Nexus of Power: Warfare, Market, and State Formation in Late Imperial China, 1000-1600." Utrecht, World Economic History Conference, 2009. 
Lorge, P. War, Politics and Society in Early Modern China: 900-1795. London: Routledge, 2005.

Lucas, R. E. "Making a Miracle." Econometrica 61, no. 2 (1993): 251-72.

Lynn, J. A. Giant of the Grand Siècle: The French Army, 1610-1715. Cambridge, UK and New York: Cambridge University Press, 1997.

"International Rivalry and Warfare." In The Eighteenth Century, edited by T. C. W. Blanning, 178-217. New York: Oxford University Press, 2000.

Machiavelli, Niccolo. The Prince. Tr. James B. Atkinson. Indianapolis: Bobbs-Merrill, 1977.

Mallett, M. E. Mercenaries and Their Masters: Warfare in Renaissance Italy. Totowa, NJ: Rowman and Littlefield, 1974.

Martin, C., and G. Parker. The Spanish Armada. Manchester: Manchester University Press, 1999.

Mathias, P., and P. O'Brien. "Taxation in Britain and France, 1715-1810: A Comparison of the Social and Economic Incidence of Taxes Collected for the Central Government." Journal of European Economic History 5 (1976): 601-50.

Mattingly, G. "International Diplomacy and International Law." The New Cambridge Modern History, edited by R. B. Wernham, 149-70. Cambridge: Cambridge University Press, 1968.

McBride, M., and S. Skaperdas. "Explaining Conflict in Low-Income Countries: Incomplete Contracting in the Shadow of the Future. In Institutions and Norms in Economic Development, edited by M. Gradstein and K. A. Konrad, 141-61. Cambridge, MA: MIT, 2007.

McNeill, W. H. Europe's Steppe Frontier. Chicago: University of Chicago Press, 1964.

Minost, L. "Jean II Maritz (1711-1790): La fabrication des canons au XVIIIe siècle." Cahiers d'Etudes et de Recherches du Musée de l'Armée hors-série numéro 2 (2005): 1-287.

Mokyr, J. The Gifts of Athena: Historical Origins of the Knowledge Economy. Princeton, NJ: Princeton University Press, 2002.

Murphey, R. "The Ottoman Attitude Towards the Adoption of Western Technology: The Role of Efrenci Technicians in Civil and Military Applications." In Contributions à l'histoire économique et sociale de l'Empire ottoman, edited by J. L. BacquéGramont and P. Dumont, 287-98. Louvain, Belgique: Peeters Publishers, 1983.

Myers, R. H., and Y.-C. Wang. "Economic Developments, 1644-1800." In The Cambridge History of China, Volume 9, edited by J. K. Fairbank and D. C. Twitchett, 563-646. Cambridge: Cambridge University Press, 2002.

Needham, J. Science and Civilisation in China. Cambridge: Cambridge University Press, 1954-.

Pamuk, S., and K. Karaman. "Ottoman State Finances in European Perspective, 1500-1914." The Journal of Economic History 70, no. 3 (2010): 593-627.

Parker, G. The Military Revolution: Military Innovation and the Rise of the West, 1500-1800. Cambridge, UK and New York: Cambridge University Press, 1996.

Parrot, D. Richelieu's Army: War, Government, and Society in France, 1624-1642. Cambridge: Cambridge University Press, 2001.

Parry, V. J., and M. E. Yapp, eds. War, Technology, and Society in the Middle East. London: Oxford University Press, 1975.

Parthasarathi, P. Why Europe Grew Rich and Asia Did Not: Global Economic Divergence, 1600-1850. Cambridge: Cambridge University Press, 2011. 
Paul, M. C. "The Military Revolution in Russia, 1550-1682." Journal of Military History 68, no. 1 (2004): 9-45.

Perdue, P. C. China Marches West: The Qing Conquest of Central Eurasia. Cambridge, MA: Belknap Press of Harvard University Press, 2005.

Pettegree, A. "Elizabethan Foreign Policy." The Historical Journal 31, no. 4 (1988): 965-72.

Pintner, W. M. "The Burden of Defense in Imperial Russia, 1725-1914." Russian Review 43, no. 3 (1984): 231-59.

Powell, R. "Guns, Butter, and Anarchy." The American Political Science Review 87, no. 1 (1993): 115-32.

Pryor, J. R. Geography, Technology, War: Studies in the Maritime History of the Mediterranean, 649-1571. Cambridge: Cambridge University Press, 1988.

Reischauer, E. O., J. K. Fairbank, and A. M. Craig. A History of East Asian Civilization. Boston: Houghton Mifflin, 1960.

Rodger, N. A. M. The Command of the Ocean: A Naval History of Britain, 1649-1815. New York: W. W. Norton \& Company, 2004.

Rossabi, M. "The Ming and Inner Asia." In The Cambridge History of China, Volume 8, edited by D. C. Twitchett and F. W. Mote, 221-71. Cambridge: Cambridge University Press, 1998.

Roy, K. "The Hybrid Military Establishment of the East India company in South Asia: 1750-1849." Journal of Global History 6, no. 2 (2011):195-218.

Roy, T. "Rethinking the Origins of British India: State Formation and Military-Fiscal Undertakings in an Eighteenth-Century World Region.” Beijing, Centre for China in the World Economy, Tsinghua University, 2010.

Schroeder, P. The Transformation of European Politics, 1763-1848. Oxford: Oxford University Press, 1994.

Smith, T. C. "The Land Tax in the Tokugawa Period." The Journal of Asian Studies 18, no. 1 (1958): 3-19.

Sng, T.-H. "Size and Dynastic Decline: The Principal Agent Problem in Late Imperial China, 1700-1850." Unpublished Manuscript, Princeton University, Niehaus Center for Globalization and Governance, 2011.

Sonnino, P., ed. Louis XIV King of France and of Navarre: Mémoires for the Instruction of the Dauphin. New York, Free Press, 1970.

Spence, J. D. To Change China: Western Advisers in China, 1620-1960. Boston: Little Brown, 1969.

Stearns, P. N., ed. The Encyclopedia of World History. Boston: Houghton Mifflin, 2001.

Stein, B. "State Formation and Economy Reconsidered." Modern Asian Studies 19, no. 3 (1984): 387-413.

Subrahmanyam, S. "The Kagemusha Effect: The Portuguese Firearms and the State in Early Modern South India.” Moyen Orient et Océan Indien, XVIe-XIXe siècles 4 (1987): 97-123.

Tilly, C. Coercion, Capital, and European States, AD 990-1990. Cambridge, MA: Blackwell, 1990.

Totman, C. "Review of Giving Up the Gun: Japan's Reversion to the Sword, 1543-1879. By Noel Perrin.” The Journal of Asian Studies 39, no. 3 (May 1980): 599-601.

Väth, A. Johann Adam Schall von Bell S. J. Missionar in China, kaiserlicher Astronom und Ratgeber am Hofe von Peking, 1592-1666. Nettetal: Steyler Verlag, 1991. 
Waley-Cohen, J. "China and Western Technology in the Late Eighteenth Century." The American Historical Review 98, no. 5 (1993): 1525-44.

Washbrook, David. "Progress and Problems: South Asian Economic and Social History, c. 1720-1860." Modern Asian Studies 22, no. 1 (1988): 57-96.

Williams, R. The Works of Sir Roger Williams. Oxford: Oxford University Press, 1972.

Wright, Q. A Study of War. Chicago: University of Chicago Press, 1942.

Wrigley, E. A., and R. S. Schofield. The Population History of England, 1541-1871: A Reconstruction. Cambridge: Cambridge University Press, 1989. 